\title{
Thermochemical Decomposition of Sewage Sludge - An Eco-Friendly Solution for a Sustainable Energy Future by Using Wastes
}

\author{
ANCA ZAHARIOIU ${ }^{1,2}$, FELICIA BUCURA ${ }^{1}$, EUSEBIU ILARIAN IONETE ${ }^{1}$, \\ ROXANA ELENA IONETE ${ }^{1}$, DANIELA EBRASU ${ }^{1}$, CLAUDIA SANDRU ${ }^{1}$, \\ FLORIAN MARIN ${ }^{1}$, SIMONA OANCEA ${ }^{2}$, VIOLETA NICULESCU ${ }^{1}$, \\ MARIUS GHEORGHE MIRICIOIU ${ }^{1,3^{*}}$, MARIUS CONSTANTINESCU ${ }^{1,2 *}$ \\ ${ }^{1}$ National Research and Development Institute for Cryogenic and Isotopic Technologies - ICSI Rm. Valcea, 4 Uzinei Str., \\ 240050 Ramnicu Valcea, Romania \\ ${ }^{2}$ Faculty of Agricultural Sciences, Food Industry and Environmental Protection, "Lucian Blaga” University of Sibiu, 7-9 I. Ratiu \\ Str., 550012 Sibiu, Romania \\ ${ }^{3}$ Politehnica University of Bucharest, Faculty of Applied Chemistry and Materials Science, 1-7 Polizu Str., 011061 Bucharest, \\ Romania
}

\begin{abstract}
The study aims to promote clean energy technologies that ensure the recycling and recovery of waste, namely the sewage sludge (SS), by converting it into products (e.g. oil, gas) with added value, contributing thus to reducing the negative impact on environment and health. An experimental setup was proposed in order to achieve the pyrolysis process, by varying the heating rate, $\left(5^{\circ} \mathrm{C} / \mathrm{min}, 10^{\circ} \mathrm{C} / \mathrm{min}\right.$ and

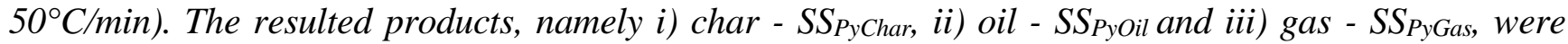
investigated in terms of elemental content, high heat value (HHV), low heat value (LHV) and emission factor (EF). The pyrolysis oils obtained with lower heating rate, $5^{\circ} \mathrm{C} / \mathrm{min}$ and $10^{\circ} \mathrm{C} / \mathrm{min}$, presented higher $H H V$, in comparison with the oils obtained at $50^{\circ} \mathrm{C} / \mathrm{min}$, which were rich in water. These oils can have a negative impact on the environment, through their combustion due to their high content of $N(6 \mathrm{wt} \%)$ and $S(1.2 \mathrm{wt} \%)$, responsible for the formation of NOx and SOx. Pyrolysis gas revealed in its composition high contents of hydrocarbons $\left(\mathrm{C}_{1}-\mathrm{C}_{6}\right)$, carbon dioxide $\left(\mathrm{CO}_{2}\right)$ and hydrogen $\left(\mathrm{H}_{2}\right)$. The highest $\mathrm{HHV}$ was obtained by using $5^{\circ} \mathrm{C} / \mathrm{min}$ increment, namely $33.81 \mathrm{MJ} / \mathrm{m}^{3}$. Also, the pyrolysis gases had comparable energy values with natural gas, biogas or gases resulted from the plastic pyrolysis.
\end{abstract}

Keywords: gas, heat value, oil, pyrolysis, sewage sludge

\section{Introduction}

1. The economic growth generated by rising living standards and technological levels, along with climate changes, due to greenhouse gas emissions and the acute shortage of resources are among the major challenges for a sustainable development. Therefore, the modern society is looking for new sources of raw materials that can be exploited over a longer sustainable time, but with energy values similar to fossil resources and without affecting the quality of the environment and life [1]. In the last decade, the industry development and the rapid urbanization led to the waste increase, as well as of the sewage sludge (SS), produced in the biological wastewater treatment plants (WWTP), through the anaerobic fermentation of organic particles.

The municipal and industrial water is treated before being discharged into rivers in order to remove the pollutants. Wastewater contains a number of organic, inorganic, toxic and pathogenic components [2-5]. Pollutants form a semi-solid residue in wastewaters, namely sewage sludge, which require sterilization, stabilization and disposal treatments [6, 7]

Sewage sludge (SS) is rich in nitrogen, phosphorus and potassium, being used worldwide in agricultural-forestry area, as an "ideal fertilizer", due to its low cost and abundance.

\footnotetext{
*email:marius.miricioiu@icsi.ro,marius.constantinescu@icsi.ro
} 
In 2014, all European Union (EU) member countries used the SS for agriculture purposes, generating undesirable emissions for both soil and water. For example, the highest percentage of SS used in agriculture was in Ireland, $70 \%$, followed by Bulgaria and France with $~ 50 \%$ and $\sim 45$, respectively [8]. At the opposite were Malta, Netherlands, Slovakia and Slovenia with less than $1 \%$.

However, due to the presence of potential toxic compounds (e.g. polycyclic aromatic hydrocarbon, heavy metals, dioxins, furans or drugs) the EU restricted the utilisation of SS in agriculture for soil fertilization [9-12].

The pollutants, mainly the heavy metal accumulations in water and in soil, along with the carbon dioxide $\left(\mathrm{CO}_{2}\right)$, have a hazardous impact on the environment [13]. Therefore, it is important to develop environmentally friendly methods to recycle the waste and to reduce the hazards caused by sludge. One of these methods can be the pyrolysis process, due to the thermal decomposition of organic substances of the sewage sludge, in the absence of oxygen, which generates products, such as bio-char, liquid bio-oil and non-condensable gas [14-16]. Also, this method can be a solution for sewage sludge volume reduction [17].

The char resulted as by-product from the sewage sludge pyrolysis (SS) can be used to improve the soil fertility and to increase the cationic capacity, $p \mathrm{H}$ value and soil ability to retain water [18-20]. Also, the sludge mixed with coffee ground residues, resulted from instant coffee processing, conducted to the obtaining of solid biofuels [21]. The thermogravimetric analysis of raw materials and blends, in air $\left(\mathrm{O}_{2} / \mathrm{N}_{2}\right.$, 21/79) and oxy-fuel $\left(\mathrm{O}_{2} / \mathrm{CO}_{2}, 21 / 79\right)$ atmospheres, revealed that the replacement of $\mathrm{N}_{2}$ with $\mathrm{CO}_{2}$ decreases the burnout performance. The resulted NO emissions, after the char combustions, were lower for blends than for sewage sludge [21].

Food production derived waste by mixing with sewage sludge, under subcritical hydrothermal conditions, conducted to the production of gas, oil and solid fuels [22]. Also, the obtained solids biochar and the effluent water can be used as agricultural biochar and liquid fertilizer, respectively, due to the organic carbon content and the small concentration of nitrogen [22].

The main objective of this study was to assess the feasibility of eliminating SS along with exploiting its valorisation for energy purposes. Therefore, it was investigated the pyrolysis process, at different pyrolysis heating rates, by using the sewage sludge as raw materials in order to obtain products with added value. The pyrolysis products (oil, char and gas) and the waste were characterized by different techniques, to better understand the properties of the obtained alternative fuels and the influence of heating rate.

\section{Materials and methods}

\subsection{Sewage sludge samples}

The SS samples were collected during February - April 2019, from the wastewater treatment plants in Ramnicu Valcea city, Romania, after the anaerobic digestion [23]. Regarding the textural characteristic, the SS was similar to a clay, with high humidity, over $80 \%$.

\subsection{Analytical investigations}

The SS samples were firstly characterized in term of their organic content. In this respect, the SS was subjected to an investigation of the ${ }^{13} \mathrm{C}$ content by using an elemental analyzer (Flash EA1112 HT, Thermo Scientific, Italy).

The liquids obtained from the pyrolysis process were separated through centrifugation $-\left(\right.$ Hettich ${ }^{\circledR}$ EBA 20, Sigma Aldrich, Germany).

The analysis of elements, such as carbon $(\mathrm{C})$, hydrogen $(\mathrm{H})$ and oxygen $(\mathrm{O})$ in SS samples and derived products (char and oil), was performed with an elemental analyzer (EA2000, Thermo Scientific, UK). Elements with negative impact, such as nitrogen $(\mathrm{N})$, sulfur $(\mathrm{S})$ and carbon $(\mathrm{C})$ were investigated by combustion and pyrolysis, in interval $850-1060^{\circ} \mathrm{C}$ [24-26]. The obtained gases, after the pyrolysis, were separated through capillary columns packed with molecular sieve - SM 5A for carbon monoxide (CO) and polymer - Porapak $\mathrm{Q}$ for nitrogen dioxide $\left(\mathrm{NO}_{2}\right)$, carbon dioxide $\left(\mathrm{CO}_{2}\right)$, water $\left(\mathrm{H}_{2} \mathrm{O}\right)$ and sulfur dioxide $\left(\mathrm{SO}_{2}\right)$ and analysed by TCD detector. Methionine (Thermo Fisher Scientific, Cambridge, UK) was used 
as reference material, containing: $40.26 \mathrm{wt} \% \mathrm{C}, 7.37 \mathrm{wt} \% \mathrm{H}, 21.46 \mathrm{wt} \% \mathrm{~S}, 21.55 \mathrm{wt} \% \mathrm{O}$ and $9.35 \mathrm{wt} \% \mathrm{~N}$. Further, the measurements were validated by using cysteine (Thermo Fisher Scientific, Cambridge, UK), which has in composition: $29.95 \mathrm{wt} \% \mathrm{C}, 5.09 \mathrm{wt} \% \mathrm{H}, 26.67 \mathrm{wt} \% \mathrm{~S}, 26.67 \mathrm{wt} \% \mathrm{O}$ and $11.59 \mathrm{wt} \% \mathrm{~N}$.

The heating values (higher heating value - HHV and lower heating value - LHV) of the SS and pyrolysis products were determined with a calorimeter (C5000, IKA, Germany), via combustion method [27].

The composition of the pyrolysis gases was established by using the gas chromatography (CP 3800 Varian Inc., USA) and the applied method was also used in previous studies for natural gas and biogas evaluation [28-30].

The oils, resulted from pyrolysis process, were analysed by using Fourier transform infrared spectroscopy (Perkin Elmer, Massachusetts, USA) in transmission, in the range $400-4000 \mathrm{~cm}^{-1}$ and with a resolution of $4 \mathrm{~cm}^{-1}$. Thus, the samples were deposited on thallium-indium bromide (KRS-5), a material that does not absorb in the selected infrared domain. Also, the organic compounds were confirmed through gas chromatography coupled with mass spectrometry (Varian 450 GC-Varian 240 MS, California, USA).

In order to analyze the silica from oils it was used a high-resolution continuous source atomic absorption spectrometer (ContrAA 700, Analytik Jena AG, Jena, Germany), equipped with a standard burner head for the $\mathrm{N}_{2} \mathrm{O}-\mathrm{C}_{2} \mathrm{H}_{2}$ flame. Further, there were analyzed the elements content, such as $\mathrm{Cr}, \mathrm{Mn}$, $\mathrm{Co}, \mathrm{Ni}, \mathrm{As}, \mathrm{Sr}, \mathrm{Cd}, \mathrm{Hg}$, and $\mathrm{Pb}$, in oils by using inductively coupled plasma mass spectrometer (Varian 820, Varian, Australia), equipped with a micro mist ultrasonic nebulizer.

\subsection{Experimental set-up}

\subsubsection{Humidity extraction}

The moisture extraction from the SS samples was achieved in a solar drying equipped with humidity extractor [31]. For sample drying it was required a time of $48 \mathrm{~h}$, until the moisture decreased below $5 \%$. After this step, the resulted products were ground and sieved in order to obtain particles with size below $200 \mu \mathrm{m}$.

\subsubsection{Pyrolysis process}

The pyrolysis process was performed by using a lab-designed installation that is illustrated in Figure 1 .

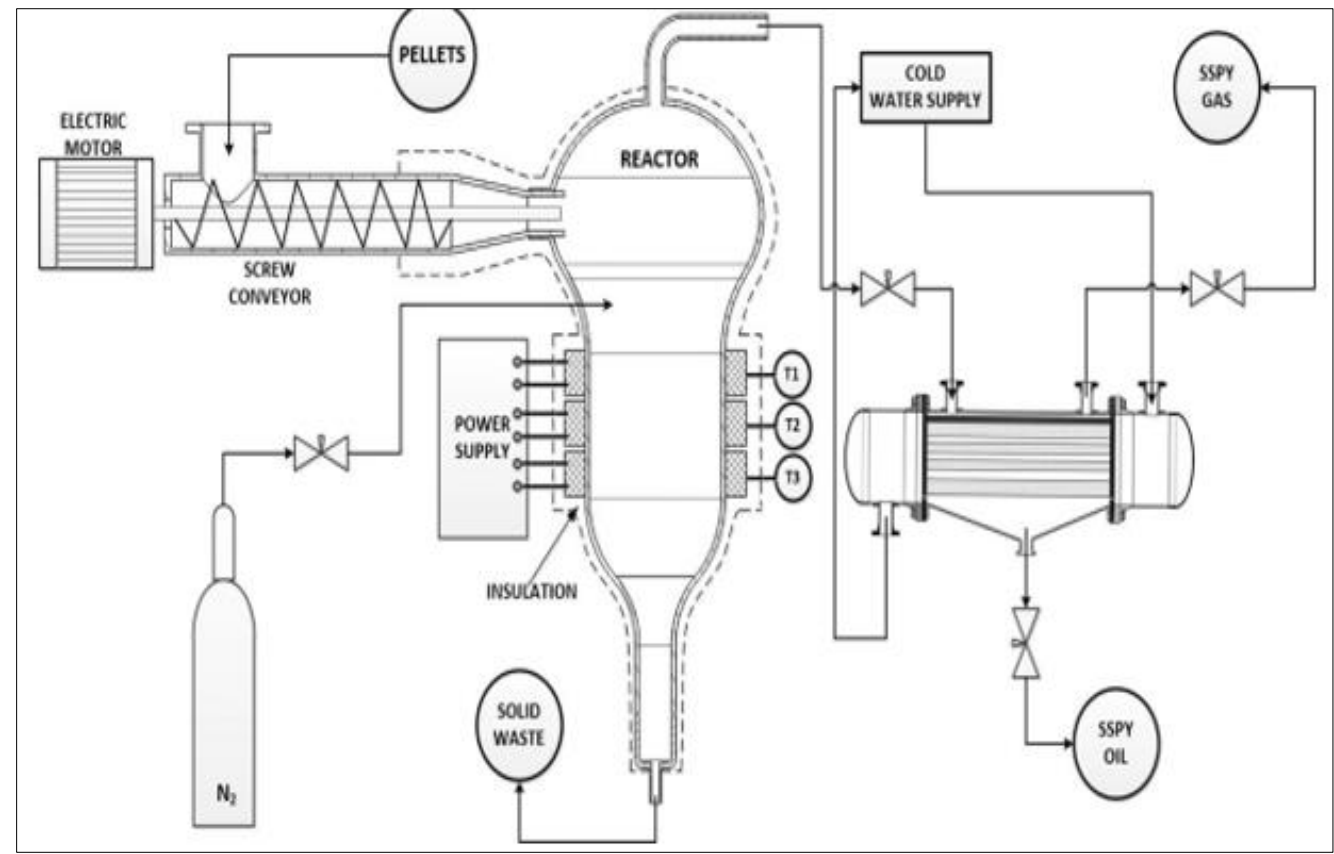

Figure 1. Experimental setup for sewage sludge pyrolysis 
The main components of the experimental setup used in this study are: the sample feeder, the pyrolysis reactor and the condenser. The pyrolysis experiments were performed by using a SS quantity of $25 \mathrm{~g}$. Thus, the SS was pushed into the reactor by the screw conveyor and then was heated until the temperature of $450^{\circ} \mathrm{C}$ was achieved. To reduce the oxygen level and to avoid the formation of environmentally harmful oxide compounds, it was assured a flow rate of $100 \mathrm{~mL} / \mathrm{min}$ of high purity $\mathrm{N}_{2}(99.999 \mathrm{vol} \%$, Linde Gas, Germany), during the pyrolysis process. Prior to the experiments, it was calculated the required time for the total inertization, this being directly proportional with the inert gas flow and with the installation volume.

The unique design of the reactor, made from refractory steel, allows the continuous feeding process with SS and the superior spherical shape permits a longer contact between the raw material and the vapours, conducting to a better "extraction" of elements with high energy values, such as $\mathrm{H}_{2}, \mathrm{HCs}$, and $\mathrm{O}_{2}$. To avoid the heat loss, the reactor was isolated with quartz and basalt wool (1:1), with a thickness of 5 mm.

The pyrolysis vapors pass quickly through the condenser, in about $20 \mathrm{~s}$. The collected reaction products, during the pyrolysis process (at $450^{\circ} \mathrm{C}$ ), were: (i) the liquid ( $\mathrm{SS}_{\text {PyOil }}$ ) - a semi-viscous mixture of black tar, water and oils; (ii) the non-condensable gases ( $\left.\mathrm{SS}_{\mathrm{PyGas}}\right)-\mathrm{H}_{2}, \mathrm{O}_{2}, \mathrm{HCs}, \mathrm{H}_{2} \mathrm{~S}, \mathrm{CO}, \mathrm{CO}_{2}$ and (iii) the solid char ( $\left.\mathrm{SS}_{\mathrm{PyChar}}\right)$. Further, the pyrolysis products quantities (wt\%) were calculated by using the equation (1):

$$
S S_{\text {PyGas }}=100-\left(S S_{\text {PyChar }}+S S_{\text {Pyoil }}\right)
$$

The reactor design permits to perform the pyrolysis tests by using dried SS samples and by varying the heating rate, namely $5^{\circ} \mathrm{C} / \mathrm{min}, 10^{\circ} \mathrm{C} / \mathrm{min}$ or $50^{\circ} \mathrm{C} / \mathrm{min}$, in order to observe the changes in resulted products (SS $S_{\text {PyChar, }}$ SS $S_{\text {PyOil }}$ and $\mathrm{SS}_{\text {PyGas }}$ ).

\section{Results and discussions}

In figure 2 are presented the ratios of liquid, gas and char (solid residue) obtained at different heating rates $\left(5^{\circ} \mathrm{C} / \mathrm{min}, 10^{\circ} \mathrm{C} / \mathrm{min}\right.$ or $\left.50^{\circ} \mathrm{C} / \mathrm{min}\right)$ of pyrolysis process.

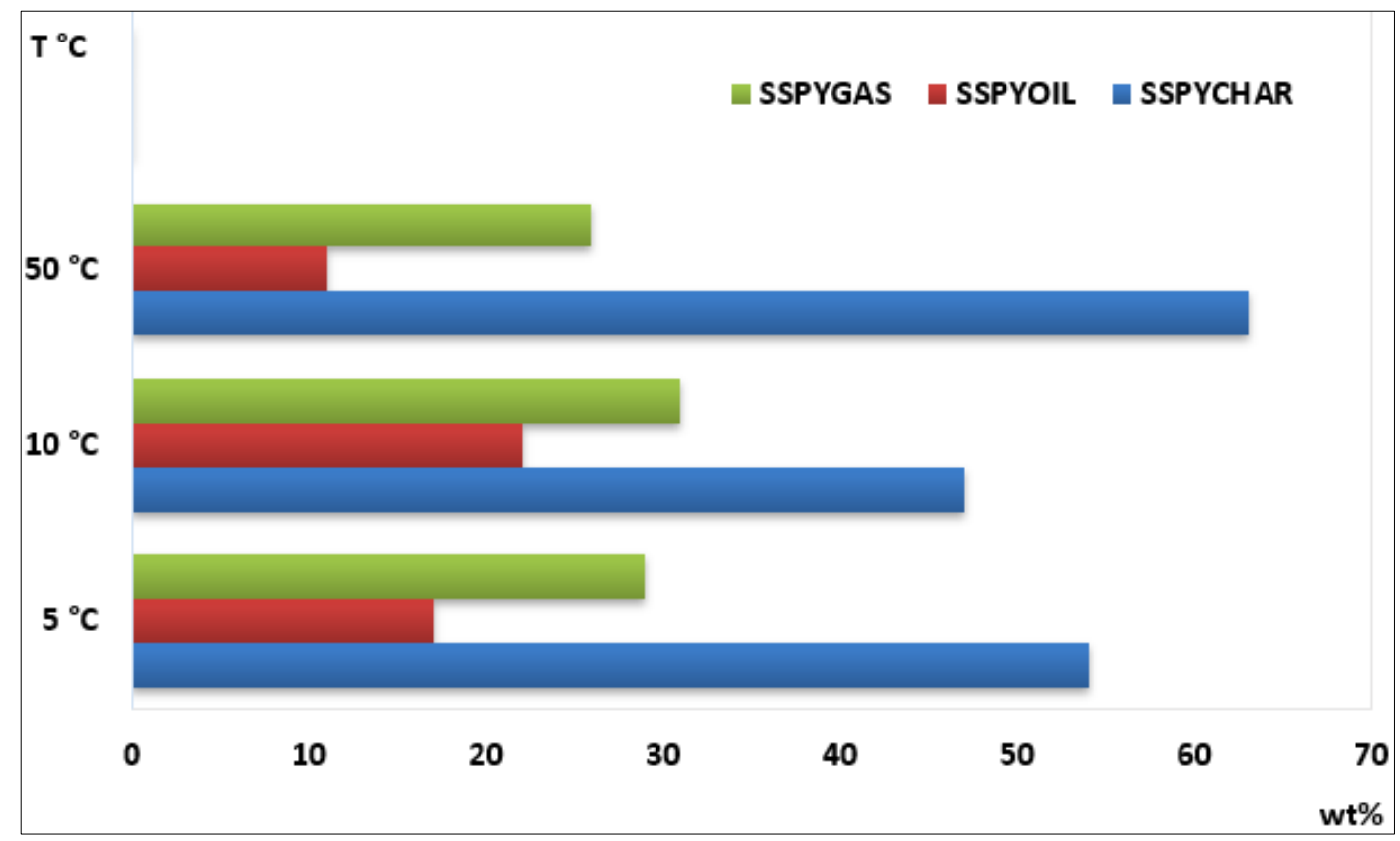

Figure 2. Variation of the yields of SSPyChar, SSPyOil and SSPyGas with the pyrolysis heating rate 
Each series represents an average of 2 independent experiments in the same technical conditions, with a relative standard deviation below 5\%. It can be observed that the highest content of char was obtained when the pyrolysis process was carried out with the heating rate of $50^{\circ} \mathrm{C} / \mathrm{min}$. The highest contents of gas and oil were obtained at the same heating rate, namely $10^{\circ} \mathrm{C} / \mathrm{min}$.

\subsection{SS and SSPyChar properties}

The ${ }^{13} \mathrm{C}$ investigation of the collected SS samples revealed a content over $95 \%$ of organic matter. Also, it was achieved a specific activity of $197+/-0.015 \mathrm{~Bq} / \mathrm{kg} \mathrm{C}$, thus the fossil carbon intake being in interval $10.9-23 \%$.

The properties of both, SS and derived residue (SSyChar), resulted at different heating rate of pyrolysis process, are highlighted in Table 1 . There were achieved HHVs around $2600 \mathrm{kcal} / \mathrm{kg}$, in all cases, being between the values recorded in literature [32] and higher than the lignite HHV ( $2100 \mathrm{kcal} / \mathrm{kg})[23]$.

Table 1. SS and SS $S_{\text {PyChar }}$ properties

\begin{tabular}{|c|c|c|c|c|}
\hline \multirow{3}{*}{ Parameter } & \multirow{3}{*}{ SS } & \multicolumn{3}{|c|}{ SSPyChar } \\
\hline & & \multicolumn{3}{|c|}{ Heatig rate } \\
\hline & & $5^{\circ} \mathrm{C} / \mathrm{min}$ & $10^{\circ} \mathrm{C} / \mathrm{min}$ & $50^{\circ} \mathrm{C} / \mathrm{min}$ \\
\hline $\mathrm{W}(\mathrm{wt} \%)$ & 82.37 & 1.09 & 0.79 & 1.25 \\
\hline $\mathrm{A}(\mathrm{wt} \%)$ & 33.88 & 63.30 & 68.33 & 60.99 \\
\hline $\mathrm{V}(\mathrm{wt} \%)$ & 55.71 & 10.96 & 8.67 & 6.53 \\
\hline $\mathrm{C}(\mathrm{wt} \%)$ & 34.51 & 29.46 & 29.00 & 28.98 \\
\hline $\mathrm{H}(\mathrm{wt} \%)$ & 5.01 & 1.17 & 1.04 & 1.33 \\
\hline $\mathrm{N}(\mathrm{wt} \%)$ & 6.26 & 4.13 & 4.88 & 4.19 \\
\hline $\mathrm{S}(\mathrm{wt} \%)$ & 0.86 & 0.47 & 0.46 & 0.56 \\
\hline $\mathrm{O}(\mathrm{wt} \%)$ & 17.11 & 0.38 & 0.67 & 1.08 \\
\hline $\mathrm{C}^{\mathrm{fix}}(\mathrm{wt} \%)$ & 8.04 & 24.65 & 25.77 & 24.65 \\
\hline HHV (kcal/kg) & 3456 & 2633 & 2559 & 2539 \\
\hline LHV (kcal/kg) & 3000 & 2209 & 2179 & 2007 \\
\hline $\mathrm{EF}(\mathrm{t} / \mathrm{TJ})$ & 92.05 & 103.14 & 104.04 & 106.98 \\
\hline
\end{tabular}

Taking into account the high level of ash (> $60 \mathrm{wt} \%$ ), caused by combustion of SSPyChar, due to inorganic phase, and to its content of nitrogen ( $>4 \mathrm{wt} \%)$, this solid could not be an attractive fuel.

Also, the metals associated with the inorganic content of the SS remained in the SS PyChar, being a distinct characteristic of the solid residue derived from the SS compared to those from lignocellulosic origin [12].

The different heating rates, used during experiments, did not influence the elemental composition of

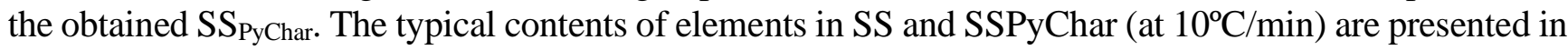
Table 2.

Table 2. Elements level in SS PyChar compared to SS

\begin{tabular}{|c|c|c|c|c|c|c|c|c|}
\hline Material & Element c & concentrat & ion $(\mathrm{n}$ & $\mathrm{ng} / \mathrm{g}$ & & & & \\
\hline & \begin{tabular}{l|l}
$\mathrm{Cr}$ & $\mathrm{Fe}$ \\
\end{tabular} & $|\mathbf{M n}| \mathbf{N i}$ & $\mathrm{Cu}$ & $\mathrm{Zn}$ & $\mathrm{K}$ & $\mathrm{Na}$ & & \\
\hline SS & \begin{tabular}{|l|l|l|}
0.195 \\
\end{tabular} & \begin{tabular}{|l|l|l|}
0.14 & 0.02 \\
\end{tabular} & 0.36 & 0.11 & & & & 144.75 \\
\hline$S_{S}$ & $0.45 \mid 0.09$ & \begin{tabular}{|l|l|l|}
0.23 & 0. \\
\end{tabular} & 1.64 & 1.52 & & 2.6 & 0.06 & 323.32 \\
\hline
\end{tabular}

Despite its high energy content, due to the presence of elements, such as $\mathrm{H}, \mathrm{C}$ and $\mathrm{O}$ (Table 1), the SSPyChar has also high concentration of metals (Table 2).

\subsection{SSPyOil properties}

The condensed vapor resulted in this process represents the liquid fraction between the reaction products. Thus, the obtained products were introduced in polypropylene capsules and centrifuged at 5000 $\mathrm{rpm} / \mathrm{min}$, the solutions being separated into three fractions, namely $\sim 15 \mathrm{wt} \%$ aqueous, $\sim 83 \mathrm{wt} \%$ viscous 
and $\sim 2 \mathrm{wt} \%$ solid particles (tar). Tables 3 and 4 summarize the elemental compositions and the energy values of the oils resulted in this study against the values of various oils from different studies $[1,11,12$, 33-35].

Table 3. SS PyOil properties

\begin{tabular}{|c|c|c|c|c|c|c|c|c|}
\hline \multirow{2}{*}{ Parameter } & SSPyOil & SSPyOil & SSPyOil & \multirow{2}{*}{ SSPyOil [1] } & \multirow{2}{*}{ SSPyOil [11] } & \multirow{2}{*}{$\begin{array}{c}\text { SSPyOil } \\
{[12]}\end{array}$} & \multirow{2}{*}{$\begin{array}{c}\text { SSPyoil } \\
{[34]}\end{array}$} & \multirow{2}{*}{$\begin{array}{c}\text { SSPyOil } \\
{[33]}\end{array}$} \\
\hline & $5^{\circ} \mathrm{C} / \mathrm{min}$ & $10^{\circ} \mathrm{C} / \mathrm{min}$ & $50^{\circ} \mathrm{C} / \mathrm{min}$ & & & & & \\
\hline $\mathrm{W}(\mathrm{wt} \%)$ & $<1$ & $<1$ & $66-70 \pm 7.75$ & $<1$ & $<1$ & 10.90 & - & - \\
\hline $\mathrm{C}(\mathrm{wt} \%)$ & $64.45 \pm 1.81$ & $72.52 \pm 2.05$ & $23.09 \pm 0.65$ & - & - & - & $49.10-62.70$ & $29.60-36.0$ \\
\hline $\mathrm{H}(\mathrm{wt} \%)$ & $8.97 \pm 0.23$ & $9.09 \pm 0.23$ & $4.14 \pm 0.10$ & - & - & - & 9.80-11.5 & $0.70-5.20$ \\
\hline $\mathrm{N}(\mathrm{wt} \%)$ & $6.30 \pm 0.30$ & $5.84 \pm 0.27$ & $7.19 \pm 0.34$ & - & - & - & $5.20-5.75$ & $1.40-3.80$ \\
\hline $\mathrm{S}(\mathrm{wt} \%)$ & $1.12 \pm 0.05$ & $1.27 \pm 0.06$ & $2.03 \pm 0.10$ & - & - & - & $0.43-0.56$ & $0.52-0.72$ \\
\hline $\mathrm{O}(\mathrm{wt} \%)$ & $19.16 \pm 0.59$ & $11.98 \pm 0.37$ & - & - & - & 28.6 & $20.40-34.80$ & $1.50-25.40$ \\
\hline HHV (kcal/kg) & $7230 \pm 90$ & $8126 \pm 100$ & $1230 \pm 15$ & 6000 & 7729 & 5804-8980 & $4922-5193$ & 2613-3955 \\
\hline LHV (kcal/kg) & $6760 \pm 84$ & $7650 \pm 95$ & $769 \pm 9.54$ & 5700 & 7215 & $5300-8122$ & $4417-4609$ & $2100-3421$ \\
\hline $\mathrm{EF}(\mathrm{t} / \mathrm{TJ})$ & 82.18 & 82.27 & - & - & - & - & - & - \\
\hline$\rho 25^{\circ} \mathrm{C}\left(\mathrm{g} / \mathrm{cm}^{3}\right)$ & 1.06 & 1.21 & - & - & - & - & - & - \\
\hline Colour/viscosity & $\begin{array}{l}\text { black/ } \\
\text { viscous }\end{array}$ & $\begin{array}{c}\text { black/ } \\
\text { viscous }\end{array}$ & $\begin{array}{c}\text { black/ } \\
\text { aqueous }\end{array}$ & - & - & - & - & - \\
\hline
\end{tabular}

Higher HHVs were obtained for the oils resulted from pyrolysis processes which were performed at heating rates of $5^{\circ} \mathrm{C} / \mathrm{min}$ and $10^{\circ} \mathrm{C} / \mathrm{min}$. Opposite, the oil obtained with the heating rate of $50^{\circ} \mathrm{C} / \mathrm{min}$, was rich in water $(>80 \mathrm{wt} \%)$ and had a low organic fraction $(<16 \mathrm{wt} \%)$.

Table 4. Properties and specifications of oils derived from different raw materials (reported in literature)

\begin{tabular}{|c|c|c|c|c|}
\hline Parameter & $\begin{array}{c}\text { PYOIL rice hull } \\
{[\mathbf{1 1}]}\end{array}$ & $\begin{array}{c}\text { PYOIL biomass } \\
{[\mathbf{1 1}]}\end{array}$ & $\begin{array}{c}\text { PYOLL sugar cane residue } \\
{[\mathbf{1 1}]}\end{array}$ & PPOHDPE 450 [35] \\
\hline $\mathrm{W} \mathrm{wt} \%$ & - & - & - & $<1$ \\
\hline $\mathrm{C} \mathrm{wt} \%$ & - & - & - & 80.71 \\
\hline $\mathrm{H} \mathrm{wt} \%$ & - & - & - & 13.24 \\
\hline $\mathrm{N} \mathrm{wt} \%$ & - & - & - & 0.34 \\
\hline $\mathrm{S} \mathrm{wt} \%$ & - & - & - & 0.005 \\
\hline $\mathrm{O} w t \%$ & - & - & - & 5.71 \\
\hline $\mathrm{HHV} \mathrm{kcal} / \mathrm{kg}$ & 3941 & 4538 & 4872 & 11000 \\
\hline $\mathrm{LHV} \mathrm{kcal} / \mathrm{kg}$ & 3442 & 4012 & 4336 & 9756 \\
\hline $\mathrm{EF} \mathrm{t/TJ}$ & - & - & - & 67.25 \\
\hline$\rho 25^{\circ} \mathrm{C} \mathrm{g} / \mathrm{cm}^{3}$ & - & - & - & 0.76 \\
\hline Colour/viscosity & black/aqueous & - & - & yellow \\
\hline
\end{tabular}

The energy values for the pyrolysis oils obtained by using 5 and $10{ }^{\circ} \mathrm{C}$ heating rates were higher than the values of different oils obtained through the pyrolysis of various raw materials (Table 3 and Table 4). Thus, the use of these pyrolysis oils for energy purposes, either in their natural form or transformed by fractional distillation into fuels, cannot be ignored. The HHV recorded for the SS $S_{\text {PyOil }}$, obtained with a heating rate of $10^{\circ} \mathrm{C} / \mathrm{min}$, namely $8126 \mathrm{kcal} / \mathrm{kg}$, was similar to the values presented in literature $[1,11,12$, $35,36]$ and in some cases being even double $[11,33]$. In contrast, the concentration of $\mathrm{N}$ and $\mathrm{S}$, two elements with high potential for negative environmental impact, through the formation of gaseous oxides, such as $\mathrm{SO}_{\mathrm{x}}$ and $\mathrm{NO}_{\mathrm{x}}$, after the oils combustion, were higher than the data reported in literature, namely, for $\mathrm{N}$ it was obtained $6.00 \mathrm{wt} \%$ in this study in comparison with $1.50-5.60 \mathrm{wt} \%[33,37]$ and for $\mathrm{S}$ it was obtained $1.20 \mathrm{wt} \%$ in this study in comparison with $0.43-0.50 \mathrm{wt} \%[33,34]$. The high $\mathrm{N}$ content could be due to intensive utilisation of soil fertilizer for long period of time. The highest content of $\mathrm{H}$, about 9 wt $\%$, was obtained for $\mathrm{SS}_{\text {PyOil }}$ with $10^{\circ} \mathrm{C} / \mathrm{min}$ heating rate, while in the literature the values were between 0.70 and $11.50 \mathrm{wt} \%[33,34]$.

Oxygen content is very important for the pyrolysis oil due to its caloric contribution and the values obtained in this study were in interval 12.00-19.00 wt\%, comparable with oxygen values reported in 
literature, namely in interval 1.50-28.60 wt\% [12, 33, 34].

Comparing the HHV of oils obtained in this work with the data reported in literature of conventional liquid fuels [35], such as gasoline, kerosene, diesel and heavy fuel oil (Table 5), it can be observed that are similar.

Table 5. Conventional liquid fuels properties

\begin{tabular}{|c|c|c|c|c|}
\hline Parameter & $\begin{array}{c}\text { Gasoline } \\
{[\mathbf{3 5}]}\end{array}$ & $\begin{array}{c}\text { Kerosene/LFO } \\
{[\mathbf{3 5}]}\end{array}$ & $\begin{array}{c}\text { Diesel } \\
{[\mathbf{3 5}]}\end{array}$ & Heavy Fuel Oil/HFO [35] \\
\hline $\mathrm{W}(\mathrm{wt} \%)$ & $<1$ & $<1$ & $<1$ & $<1$ \\
\hline $\mathrm{C}(\mathrm{wt} \%)$ & 85.16 & 84.00 & 83.46 & 86.93 \\
\hline $\mathrm{H}(\mathrm{wt} \%)$ & 11.09 & 10.33 & 12.13 & 8.61 \\
\hline $\mathrm{N}(\mathrm{wt} \%)$ & 0.31 & 0.59 & 0.75 & 0.64 \\
\hline $\mathrm{S}(\mathrm{wt} \%)$ & 0.01 & 0.01 & 0.01 & 0.77 \\
\hline $\mathrm{O}(\mathrm{wt} \%)$ & 3.43 & 5.07 & 3.65 & 3.05 \\
\hline $\mathrm{HHV}(\mathrm{kcal} / \mathrm{kg})$ & 10451 & 9782 & 11002 & 11355 \\
\hline $\mathrm{LHV}(\mathrm{kcal} / \mathrm{kg})$ & 9566 & 9200 & 9968 & 88.16 \\
\hline $\mathrm{EF}(\mathrm{t} / \mathrm{TJ})$ & - & - & - & 0.80 \\
\hline$\rho 25^{0} \mathrm{C}\left(\mathrm{g} / \mathrm{cm}^{3}\right)$ & 0.81 & 0.84 & 0.78 & black \\
\hline $\mathrm{Colour}$ & yellow-green & yellow & yellow-green & \\
\hline
\end{tabular}

The investigation of metals content in SS is very important, therefore Table 6 reveals the metal concentrations found in pyrolysis oils, but also in different types of liquid fuels from various studies [35, 38].

Table 6. Metal concentrations in SSPyOil in comparison with data reported in literature for pyrolysis oils [35] and conventional liquid fuels [38]

\begin{tabular}{|c|c|c|c|c|c|c|c|c|}
\hline \multirow{2}{*}{ Metal } & \multirow{3}{*}{ SSPyOil } & \multicolumn{5}{|c|}{ Pyrolysis oil } & \multicolumn{3}{c|}{ Conventional fuel } \\
\cline { 3 - 10 } & & $\begin{array}{c}\text { PPOPP } \\
{[\mathbf{3 5}]}\end{array}$ & $\begin{array}{c}\text { PPOHDPE } \\
{[\mathbf{3 5}]}\end{array}$ & $\begin{array}{c}\text { PPOLDPE } \\
{[35]}\end{array}$ & $\begin{array}{c}\text { PPOPS } \\
{[\mathbf{3 5}]}\end{array}$ & $\begin{array}{c}\text { Kerosene } \\
{[\mathbf{3 8}]}\end{array}$ & $\begin{array}{c}\text { Gasoline } \\
{[\mathbf{3 8}]}\end{array}$ & $\begin{array}{c}\text { Diesel } \\
{[\mathbf{3 8}]}\end{array}$ \\
\hline $\mathrm{Cr}(\mu \mathrm{g} / \mathrm{g})$ & 1.79 & 19.27 & 91.49 & 35.11 & 106.03 & 3.30 & 5.40 & 8.60 \\
\hline $\mathrm{Mn}(\mu \mathrm{g} / \mathrm{g})$ & 0.29 & 0.29 & 8.11 & 0.01 & 0.37 & - & - & - \\
\hline $\mathrm{Co}(\mu \mathrm{g} / \mathrm{g})$ & 0.01 & 0.21 & 1.39 & 0.07 & 0.16 & - & - & - \\
\hline $\mathrm{Ni}(\mu \mathrm{g} / \mathrm{g})$ & 9.30 & 0.56 & 53.83 & 4.56 & 0.02 & - & - & - \\
\hline $\mathrm{As}(\mu \mathrm{g} / \mathrm{g})$ & 1.86 & 0.37 & 0.17 & 0.35 & 0.30 & - & - & - \\
\hline $\mathrm{Sr}(\mu \mathrm{g} / \mathrm{g})$ & 0.10 & 0.06 & 0.72 & 0.05 & 0.15 & - & - & - \\
\hline $\mathrm{Cd}(\mu \mathrm{g} / \mathrm{g})$ & 0.02 & 0.12 & 0.34 & 0.05 & 0.07 & 13.30 & 16.80 & 15.00 \\
\hline $\mathrm{Hg}(\mu \mathrm{g} / \mathrm{g})$ & 0.06 & 0.00 & 0.00 & 0.00 & 0.00 & - & 0.77 & - \\
\hline $\mathrm{Pb}(\mu \mathrm{g} / \mathrm{g})$ & 0.20 & 0.09 & 0.53 & 0.06 & 0.07 & 4.10 & 2.40 & 10.10 \\
\hline
\end{tabular}

From Table 6, it can be notice higher contents for As and $\mathrm{Hg}$ in SSPyOil than in oils obtained from $i$ ) pyrolysis of polypropylene (PPOPP), ii) high density polyethylene (PPO $\left.{ }_{\mathrm{HDPE}}\right)$, iii) low density polyethylene (PPO $\mathrm{LDPE}_{\text {) }}$ and $i v$ ) polystyrene (PPOPS) [35]. Also, the $\mathrm{Hg}$ and $\mathrm{Ni}$ contents were higher than in gasoline [38] and in pyrolysis oils obtained from different polymers [35], respectively.

The FTIR spectrum of the $\mathrm{SS}_{\text {PyOil }}$ illustrated in Figure 2, presents several vibrational bands, associated to bonds that are found in specific compounds (Table 7). 


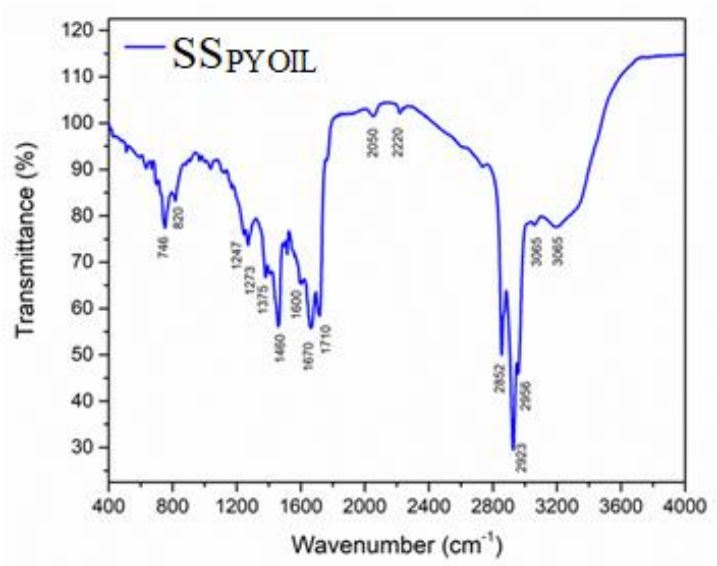

Figure 2. FTIR spectrum of SSPyOil

Table 7. FTIR results for $\mathrm{SS}_{\text {PyOil }}$

\begin{tabular}{|c|c|c|}
\hline Position of the band $\left(\mathbf{c m}^{-\mathbf{1}}\right)$ & Bond & Compound \\
\hline 746,820 & $\mathrm{C}-\mathrm{H}$ & Aromatic \\
\hline $1247,1273,1375,1460$ & $\mathrm{C}-\mathrm{H}$ & Alcan \\
\hline $1600,1670,1710$ & $\mathrm{C}=\mathrm{C}$ & Aromatic \\
\hline 2050,2220 & $\mathrm{C} \equiv \mathrm{C}$ & Terminal alkynes \\
\hline $2852,2923,2956,3065$ & $\mathrm{C}-\mathrm{H}$ & Aromatic \\
\hline 3200 & $\mathrm{O}-\mathrm{H}$ & Aromatic (phenols or alcohols) \\
\hline
\end{tabular}

Thus, the organic compounds confirmed in $\mathrm{SS}_{\text {PyOil, }}$ through chromatography coupled with mass spectrometry, were fatty acids, alcohols, amine and hydrocarbons (aromatic $>45 \%$, aliphatic, cyclic).

\subsection{SSPyGas properties}

The compositional analysis of the obtained pyrolysis gas revealed that $\mathrm{CH}_{4}, \mathrm{CO}_{2}$, and $\mathrm{H}_{2}$ are the dominant gases (Table 8). The gas composition and the energetic characteristics are presented in Table 8 , compared to data found in literature [1, 12, 28, 30, 35].

The highest value for $\mathrm{HHV}\left(33.81 \mathrm{MJ} / \mathrm{m}^{3}\right)$ was obtained when the heating rate of $5^{\circ} \mathrm{C} / \mathrm{min}$ was applied during the pyrolysis process.

Table 8. SSPyGas properties in comparison with conventional and alternative fuel gases

\begin{tabular}{|c|c|c|c|c|c|c|c|c|c|c|}
\hline \multirow{2}{*}{$\begin{array}{l}\text { Gas composition/ Energetic } \\
\text { characteristics }\end{array}$} & \multicolumn{3}{|c|}{$\begin{array}{c}\text { SSPyGas } \\
\text { (this work) }\end{array}$} & \multirow{2}{*}{$\begin{array}{c}\text { Geo- } \\
\text { gas } \\
{[28]}\end{array}$} & \multirow{2}{*}{$\begin{array}{c}\text { Natural } \\
\text { Gas } \\
{[28]}\end{array}$} & \multirow{2}{*}{$\begin{array}{c}\text { Sewage } \\
\text { Sludge/ } \\
\text { Biogas [28] }\end{array}$} & \multirow{2}{*}{$\begin{array}{c}\text { Pyrolysis } \\
\text { plastic gas [35] }\end{array}$} & \multirow{2}{*}{$\begin{array}{c}\text { Biogas } \\
\text { garbage } \\
{[30]}\end{array}$} & \multirow{2}{*}{$\begin{array}{c}\text { SSPyGas } \\
\text { [1] }\end{array}$} & \multirow{2}{*}{$\begin{array}{c}\text { SSPyGas } \\
{[12]}\end{array}$} \\
\hline & $\begin{array}{c}5 \\
{ }^{\circ} \mathrm{C} / \min \\
\end{array}$ & $\begin{array}{c}10 \\
{ }^{\circ} \mathrm{C} / \mathrm{min} \\
\end{array}$ & $\begin{array}{c}50 \\
{ }^{\circ} \mathrm{C} / \mathrm{min} \\
\end{array}$ & & & & & & & \\
\hline $\mathrm{C} 1$ (vol \%) & 33.41 & 13.75 & 7.58 & 80.79 & 91.85 & 64.22 & 3.93 & 29.12 & $8.00-26.00$ & 32.97 \\
\hline $\mathrm{C} 2(\mathrm{vol} \%)$ & 9.28 & 6.05 & 1.93 & 0.77 & 2.96 & 0.03 & 8.83 & 0.002 & $0.10-4.50$ & 8.72 \\
\hline Ethylene (vol \%) & 5.74 & 5.58 & 2.31 & 0.00 & 0.00 & 0.00 & 5.17 & 0.00 & $0.01-3.00$ & 2.83 \\
\hline $\mathrm{C} 3(\mathrm{vol} \%)$ & 3.35 & 3.26 & 1.47 & 0.14 & 0.80 & 0.01 & 19.54 & 0.01 & $0.006-0.01$ & 2.96 \\
\hline Propylene (vol \%) & 4.84 & 3.86 & 1.91 & 0.00 & 0.00 & 0.00 & 20.03 & 0.00 & 0.00 & 4.64 \\
\hline i-C4 (vol \%) & 0.32 & 0.30 & 0.22 & 0.02 & 0.25 & 0.01 & 0.15 & 0.01 & $0.01-0.05$ & 0.41 \\
\hline $\mathrm{n}-\mathrm{C} 4(\mathrm{vol} \%)$ & 0.41 & 0.45 & 0.18 & 0.02 & 0.25 & 0.01 & 12.17 & 0.01 & $0.01-0.05$ & 0.52 \\
\hline neo-C5 (vol \%) & 0.01 & 0.01 & 0.01 & 0.01 & 0.01 & 0.01 & 10.94 & 0.01 & 0.00 & 0.01 \\
\hline i-C5 (vol \%) & 0.20 & 0.06 & 0.02 & 0.01 & 0.13 & 0.01 & 0.24 & 0.01 & 0.00 & 0.25 \\
\hline n-C5 (vol \%) & 0.30 & 0.08 & 0.02 & 0.01 & 0.06 & 0.01 & 3.74 & 0.01 & 0.00 & 0.38 \\
\hline $\mathrm{C} 6+(\mathrm{vol} \%)$ & 0.30 & 0.52 & 0.21 & 0.01 & 0.06 & 0.01 & 1.42 & 0.01 & 0.00 & 0.37 \\
\hline $\mathrm{O}_{2}(\mathrm{vol} \%)$ & 0.18 & 0.01 & 0.04 & 0.61 & 0.62 & 0.04 & 0.00 & 11.16 & $0.50-3.00$ & 5.91 \\
\hline $\mathrm{H}_{2}(\mathrm{vol} \%)$ & 21.06 & 3.03 & 2.06 & 15.66 & 0.00 & 0.26 & 2.19 & 0.00 & $8.00-36.20$ & 32.51 \\
\hline $\mathrm{CO}(\mathrm{vol} \%)$ & 9.36 & 6.20 & 16.64 & 0.00 & 0.00 & 0.00 & 0.65 & 0.00 & $6.50-25.00$ & 0.15 \\
\hline $\mathrm{CO}_{2}(\mathrm{vol} \%)$ & 11.03 & 22.45 & 65.03 & 0.34 & 0.27 & 35.4 & 1.25 & 11.32 & $0.50-20.00$ & 7.09 \\
\hline $\mathrm{H}_{2} \mathrm{~S}(\mathrm{vol} \%)$ & 0.22 & 0.31 & 0.23 & 0.02 & 0.00 & 0.01 & 0.00 & 0.09 & $0.01-0.03$ & 0.35 \\
\hline $\mathrm{H}_{2} \mathrm{O}(\mathrm{vol} \%)$ & 0.01 & 0.01 & 0.01 & 0.04 & 0.00 & 0.05 & $<0.005$ & 0.00 & - & - \\
\hline $\mathrm{HHV}\left(\mathrm{MJ} / \mathrm{m}^{3}\right) 0^{\circ} \mathrm{C}$ & 33.81 & 16.05 & 9.28 & 33.55 & 40.39 & 25.72 & 99.83 & 11.00 & $13.74-16.53$ & 27.26 \\
\hline $\operatorname{NHV}\left(\mathrm{MJ} / \mathrm{m}^{3}\right) 0^{\circ} \mathrm{C}$ & 30.85 & 14.92 & 8.70 & 30.17 & 36.39 & 23.12 & 94.99 & 9.09 & $11.82-14.02$ & 24.64 \\
\hline
\end{tabular}




\begin{tabular}{|c|c|c|c|c|c|c|c|c|c|}
\hline $\mathrm{d}\left(\mathrm{kg} / \mathrm{m}^{3}\right) 0^{\circ} \mathrm{C}$ & 0.91 & 0.87 & 0.85 & - & - & - & - & - & - \\
\hline$\rho\left(\mathrm{kg} / \mathrm{m}^{3}\right) 0^{\circ} \mathrm{C}$ & 0.88 & 0.74 & 1.01 & - & - & - & - & - & - \\
\hline Wobbe No. $\left(\mathrm{MJ}^{3} \mathrm{~m}^{3}\right) 0^{\circ} \mathrm{C}$ & 35.45 & 18.67 & 10.08 & - & - & - & - & - & - \\
\hline
\end{tabular}

From Table 8 it can be notice that the heating rate influences the HHV, thus the energy values increase up to $\sim 34 \mathrm{MJ} / \mathrm{m}^{3}$ with the decrease of heating rate, this value being three times higher than the value obtained at $50^{\circ} \mathrm{C} / \mathrm{min}$. Also, the hydrocarbons content was significantly higher in the gas obtained in this study with $5^{\circ} \mathrm{C} / \mathrm{min}$, as well as the hydrogen and oxygen. The presence of hydrogen can be explained by the transition of the intramolecular content of the water contained by the SS into the gas phase. Also, the intramolecular hydrogen reacts with the organic carbon resulting hydrocarbons. During the pyrolysis several compounds are resulting (e.g. ethylene, propylene) due to cracking and dehydrogenation reactions. Thus, carbon dioxide and carbon monoxide began to form at 100 and $230^{\circ} \mathrm{C}$, respectively. A higher heating rate conducted to the carbon monoxide and carbon dioxide content increase, up to $16.64 \mathrm{vol} \%$ and $65.03 \mathrm{vol} \%$, respectively. The resulted energy values can be comparable with the values reported in literature $[1,12,28,30,35]$ for different gases, such as i) geo-gas and natural gas, ii) obtained from sewage sludge and iii) from pyrolysis of various type of raw materials (plastic and garbage). It was reported the HHV [35], for pyrolysis plastic gas, three times higher than the value

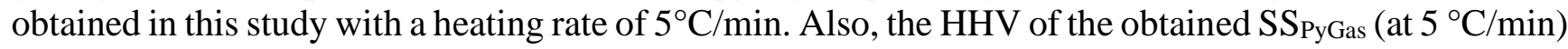
was lower than the HHV reported for natural gas [28] and higher than HHV of the pyrolysis gases obtained in other studies $[1,12]$, showing a high degree of feasibility compared to the gas mixtures obtained at higher pyrolysis temperature, namely in interval $425-850^{\circ} \mathrm{C}[39,40]$.

\section{Conclusions}

The pyrolysis of sewage sludge, at $450{ }^{\circ} \mathrm{C}$ and different heating rates $\left(5,10\right.$ and $\left.50^{\circ} \mathrm{C} / \mathrm{min}\right)$, conducted

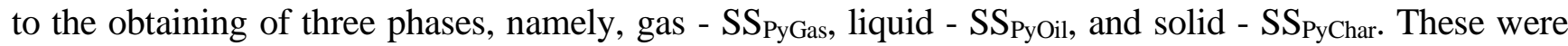
characterized in terms of energy value and elemental composition. It was demonstrated that the different heating rates have direct influence on the yields of final products. Thus, the highest content of char was obtained when a heating rate of $50^{\circ} \mathrm{C} / \mathrm{min}$ was applied. Even if the obtained $\mathrm{HHV}$ for $\mathrm{SS}_{\text {PyChar }}$ was 2600 $\mathrm{kcal} / \mathrm{kg}$, in accordance with literature, this could not be an attractive source of energy, due to its high derived ash level and to its nitrogen and metals content. Also, the $50^{\circ} \mathrm{C} / \mathrm{min}$ heating rate had a negative influence on the pyrolysis process by the obtaining of pyrolysis oil and gas with the lowest HHV. Furthermore, the oil had the highest content of $\mathrm{N}$ and $\mathrm{S}$.

The HHV of SSPyOil resulted with $10^{\circ} \mathrm{C} / \mathrm{min}$ heating rate, was similar to the values for conventional liquid fuels and higher than the HHV for pyrolysis oil derived from various raw materials, such as rice hull, biomass and sugar cane residue. Also, the $\mathrm{HHV}$ of SSPyGas resulted by using a heating rate of $5^{\circ} \mathrm{C} / \mathrm{min}$ was similar to the geo-gas and natural gas HHVs.

The sewage sludge pyrolysis can be an alternative solution for sludge use in agriculture, through unconventional fuels delivering, as in case of other wastes (raw materials).

Acknowledgments. The work has been funded by the Operational Programme Human Capital of the Ministry of European Funds through the Financial Agreement 51668/09.07.2019, SMIS code 124705, supported by NUCLEU Program, Project PN 19110301 ,Studies on the obtaining and improvement of the acido-basic properties of the nanoporous catalytic materials for application in valorisation of wastes".

\section{References}

1.KAN, T., STREZOV, V., EVANS, T., International Journal of Advances in Mechanical and Civil Engineering 2(4), 2015, p. 64. 
2.ZGAVAROGEA, R., NICULESCU, V., SANDRU, C., MIRICIOIU, M., IONETE, R., TEMPEA, I., Proceedings of the 15th International Multidisciplinary Scientific Geoconference (SGEM), Albena, Bulgaria, 18-24 June 2015, Water Resources, Forest, Marine and Ocean Ecosystems 1, p. 461

3.ZGAVAROGEA, I.R., NICULESCU, V.C., MIRICIOIU, M.G., CIUCURE, C., TEMPEA, I., J. Biotechnol. 208, 2015, p. 59

4. IORDACHE, A., IORDACHE, M., SANDRU, C., VOICA, C., STEGARUS, D., ZGAVAROGEA, R., IONETE, R.E., COTORCEA, S., MIRICIOIU, M.G., Rev. Chim. 70(10), 2019, p. 3456

5. IORDACHE, M., POPESCU, L.R., NEAMTU, S., PASCU, L.F., IORDACHE, I., Rev. Chim. 67(6), 2016, p. 1186

6.SEIFERT, H., Waste Manage. 73, 2018, p. 487.

7.ZGAVAROGEA, R.I., NICULESCU, V.C., MIRICIOIU, M.G., PAUN, N., J. Biotechnol. 231, 2016, p. 75

8.HUDCOVA, H., VYMAZAL, J., ROZKOSNY, M., Soil Water Res. 14(2), 2019, p. 104

9.GERASIMOV, G., KHASKHACHIKH, V., POTAPOV, O., DVOSKIN, G., KORNILEVA, V., DUDKINA, L., Waste Manage. 87, 2019, p. 218.

10. AGAR, D.A., KWAPINSKA, M., LEAHY, J.J., Environ. Sci. Pollut., R. 25, 2018, p. 35874.

11.VIEIRA, G.E.G., RÊGO, F., TEIXEIRA, L.F. Energy Proced.136, 2017, p. 463.

12.ARAZO, R., LUNA, M.D.G., GENUINO, D.A.D., CAPAREDA, S., Sustainable Environment Research 27(1), 2017, p.7.

13. WANG, X., CHI, Q., LIU, X., WANG, Y., Chemosphere 216, 2019, p. 698.

14. ZAKERA, A., CHENA, Z., WANGB, X., ZHANGC, Q., Fuel Process. Technol. 187, 2019, p. 84.

15. LIU, Z., SINGER, S., ZITOMER, D., MCNAMARA, P., Catalysts 8, 2018, p. 524.

16. FRISTAK, V., PIPÍSKA, M., SOJA, G., J. Clean. Prod. 172, 2018, p. 1772.

17. LEDAKOWICZA, S., STOLAREK, P., MALINOWSKI, A., LEPEZ, O., Renew. Sust. Energ. Rev. 104, 2019, p. 319.

18. MENDEZ, A., PAZ-FERREIRO, J., ARAUJO, F., GASCO, G., J. Anal. Appl. Pyrolysis 107, 2014, p. 46.

19. POKORNA, E., POSTELMANS, N., JENICEK, P., SCHREURS, S., CARLEER, R., YPERMAN, J., Fuel 88, 2009, p. 1344.

20. LARINA, O.M., ZAICHENKO, V.M., J. Phys.: Conf. Ser. 946, 2018, 012034.

21. CHEN, J., HE, Y., LIU, J., LIU, C., XIE, W., KUO, J., ZHANG, X., LI, S., LIANG, J., SUN, S., BUYUKADA, M., EVRENDILEK, F., Renew. Energ. 139, 2019, p. 707

22. FOX, J.T., ZOOK, A.N., FREISS, J., APPLEL, B., APPEL, J., OZSUER, C., SARAC, M., J. Clean Prod. 220, 2019, p. 57

23. CONSTANTINESCU, M., BUCURA, F., IONETE, R., ZAHARIOIU, A., CiUCURE, C., OANCEA, S., Proceedings of the International Scientific Multidisciplinary Conference on EARTH and GEO Sciences - SGEM, Vienna, Austria, 2017, 17(43), p. 767

24. ***ASTM D5373 - 16. Standard Test Methods for Determination of Carbon, Hydrogen and Nitrogen in Analysis Samples of Coal and Carbon in Analysis Samples of Coal and Coke.

25. ***ASTM D5291 - 16. Standard Test Methods for Instrumental Determination of Carbon, Hydrogen, and Nitrogen in Petroleum Products and Lubricants.

26. ASTM 240-17. Standard Test Method for Heat of Combustion of Liquid Hydrocarbon Fuels by Bomb Calorimeter.

27. *** ASTM E711-87(2004). Standard Test Method for Gross Calorific Value of Refuse-Derived Fuel by the Bomb Calorimeter (Withdrawn 2004).

28. BUCURA, F., IONETE, R. E., MARIN, F., MIRICIOIU, M., SAROS, G., ZAHARIOIU, A., CONSTANTINESCU, M., Progress of Cryogenics and Isotopes Separation 21(1), 2018, p. 97.

29.*** ISO 6976 (2016) Natural gas - Calculation of calorific values, density, relative density and Wobbe indices from composition. 
30. MIRICIOIU, M.G., BUCURA, F., ZAHARIOIU, A., CONSTANTINESCU, M., NICULESCU, V. Proceedings of the 17th International Multidisciplinary Scientific GeoConference SGEM 2017, Albena, Bulgaria, 29 June - 5 July 2017, 17(42), p. 3.

31.IONETE, R.E, IONETE, E.I., SPIRIDON, S.I., CONSTANTINESCU, M., Solar dryer with humidity extractor. OSIM Patent no. 132880.

32. FONTS, I., GEA, G., AZUARA, M., ABREGO, J., ARAUZO, J., Renew. Sust. Energ. Rev. 16, 2012, p. 2781.

33. INGUANZO, M., DOMÍNGUEZ, A., MENÉNDEZ, J.A., BLANCO, C.G., PIS, J.J., J. Anal. Appl. Pyrol. 63, 2002, p. 209.

34. OSPANOV, K., MYRZAHMETOV, M., ZAPPAROV, M., Procedia Engineer. 117, 2015, p. 288.

35.CONSTANTINESCU, M., BUCURA, F., IONETE, R.E., NICULESCU, V.C., IONETE, E.I., ZAHARIOIU, A., OANCEA, S., MIRICIOIU, M.G. Mater. Plast. 56(1), 2019, p. 41.

36. CONSTANTINESCU, M., BUCURA, F., IONETE E.I., ION-EBRASU, D., SANDRU, C., ZAHARIOIU, A., MARIN, F., MIRICIOIU, M.G., NICULESCU, V.C., OANCEA, S., IONETE, R.E. Mater. Plast. 56(4), 2019, p. 721.

37. VARLAM, C., STEFANESCU, I., FAURESCU, I., POPESCU, I., Proceedings of the International Conference Nuclear Energy for New Europe, Portorož, Slovenia, 18-21 September 2006.

38. AKPOVETA, V., OSAKWE, S.A., IOSR Journal of Applied Chemistry 7(6), 2014, p. 1

39. UZUN, B.B., APAYDIN-VAROL, E., ATES, F., OZBAY, N., PUTUN, A.E., Fuel 89, 2010 p. 176. 40. RAFIQ, M.K., BACHMANN, R.T., RAFIQ, M.T., SHANG, Z., JOSEPH, S., LONG, R., PLoS ONE 11(6), 2016, e0156894. doi:10.1371/journal.pone.0156894

Manuscript received: 16.04 .2020 